\title{
Age- and region-specific hepatitis B prevalence in Turkey estimated using generalized linear mixed models: a systematic review
}

Mehlika Toy ${ }^{1,2^{*}}$, Fatih Oguz Önder ${ }^{3}$, Tanja Wörmann ${ }^{4}$, A Mithat Bozdayi $i^{5}$, Solko W Schalm²,6, Gerard J Borsboom , Joost van Rosmalen ${ }^{1}$, Jan Hendrik Richardus ${ }^{1}$ and Cihan Yurdaydin ${ }^{5,7}$

\begin{abstract}
Background: To provide a clear picture of the current hepatitis B situation, the authors performed a systematic review to estimate the age- and region-specific prevalence of chronic hepatitis B (CHB) in Turkey.

Methods: A total of 339 studies with original data on the prevalence of hepatitis B surface antigen $(\mathrm{HBsAg})$ in Turkey and published between 1999 and 2009 were identified through a search of electronic databases, by reviewing citations, and by writing to authors. After a critical assessment, the authors included 129 studies, divided into categories: 'age-specific'; 'region-specific'; and 'specific population group'. To account for the differences among the studies, a generalized linear mixed model was used to estimate the overall prevalence across all age groups and regions. For specific population groups, the authors calculated the weighted mean prevalence.

Results: The estimated overall population prevalence was 4.57, 95\% confidence interval (Cl): 3.58, 5.76, and the estimated total number of CHB cases was about 3.3 million. The outcomes of the age-specific groups varied from 2.84, (95\% Cl: 2.60, 3.10) for the 0-14-yearolds to 6.36 (95\% Cl: 5.83, 6.90) in the 25-34-year-old group.

Conclusion: There are large age-group and regional differences in CHB prevalence in Turkey, where CHB remains a serious health problem.
\end{abstract}

\section{Background}

Globally, hepatitis B is one of the most common infectious diseases. Estimates indicate that at least 2 billion people have been infected with the hepatitis B virus (HBV), with more than 378 million people being chronic carriers ( $6 \%$ of the world population). Of all chronic hepatitis B (CHB) cases, approximately $40 \%$ will develop cirrhosis, liver failure, or hepatocellular carcinoma (HCC) $[1,2]$. According to the World Health Organization (WHO) classification, Turkey is one of the countries with intermediate (2\%-8\%) endemicity for hepatitis B. This information has been derived mainly from studies in blood donors. Based on these data, the overall prevalence of the hepatitis B surface antigen (HBsAg), which is a marker for chronic hepatitis B

\footnotetext{
*Correspondence: m.toy@erasmusmc.nl

'Department of Public Health, Erasmus MC, University Medical Center Rotterdam, Dr. Molewaterplein 50,3000 CA Rotterdam, the Netherlands Full list of author information is available at the end of the article
}

infection, has been reported to be between $4.0 \%$ and $5.0 \%$ [3], which has decreased to $2.0 \%$ in recent years [4]. However, this HBsAg prevalence appears to differ considerably in various parts of the country. For example, a study on the seroprevalence of HBV in children in Eastern Anatolia reveals an HBsAg prevalence of 9.8\% [5]. There is no clear picture of the current HBV situation in Turkey. A national vaccination program for the prevention of perinatal transmission of hepatitis B infection was launched in Turkey in 1998. Currently there is no routine HBsAg screening program for pregnant women in Turkey. All infants are vaccinated at birth and followed up at 1 month and again at 6 months of age.

For the planning and implementation of adequate health promotion and intervention measures, it is important for both health care providers and policy makers to know the real burden of CHB in region- and population-specific groups. In addition, migration from

\section{C) Biomed Central}

(C) 2011 Toy et al.; licensee BioMed Central Ltd. This is an Open Access article distributed under the terms of the Creative Commons Attribution License (http://creativecommons.org/licenses/by/2.0), which permits unrestricted use, distribution, and reproduction in any medium, provided the original work is properly cited 
Turkey to the European Union (EU) has important public health implications. Prevalence of hepatitis B in migrant populations in low endemic EU countries is likely to reflect the prevalence of their region of origin. It is of value for EU countries with Turkish migrants to know the country-specific prevalence of hepatitis B in order to make health policy decisions for migrants in their country [6]. This is particularly important for the timely identification and treatment of chronic HBV carriers. In order to make a best estimate for the age-specific, region-specific, and country-specific prevalence of HBsAg, we performed a systematic review of the literature on HBsAg prevalence in Turkey, focussing on ageand region-specific prevalence rates.

For optimal insight into the HBsAg prevalence in Turkey we included several study types: (i) studies employing random cluster sampling in the population; (ii) large-scale studies among blood donors and military conscripts; (iii) studies in various groups that have health-related concerns such as pregnant women and medical personnel; and finally (iv), studies in high-risk groups.

\section{Methods}

\section{Main search strategy}

This systematic review conforms to the guidelines outlined by the Meta-Analysis of Observational Studies in Epidemiology (MOOSE) [7]. For English and/or Turkish language studies, the databases MEDLINE, PUBMED, EMBASE and UlakBim (Turkish Medical Index) were searched by using the following terms: 'Hepatitis B [and] Turkey', 'HBsAg prevalence [and] Turkey'. All articles were reviewed and their corresponding reference lists inspected to identify additional material, including unpublished (grey) literature, which initially had not been detected. These were later either retrieved by a new electronic search or searched manually. The period for the meta-analysis for the age- and region-specific studies ranges from 1999-2009, so the data is coupled with results obtained after the advent of the universal immunization program in Turkey in 1999. HBsAg prevalence was estimated within 7 broad age groups (0-14, 15-24, 25-34, 35-44, 45-54, 55-64, and 65 years and older). The age groups were selected to best fit the available data extracted from the literature. For the studies on health care workers, a comparison was made between the studies from 1990-1999 and 2000-2009, in order to retrieve the risk group vaccination effect.

\section{Eligibility criteria}

First-round review criteria for selection of studies included were the availability of explicit data on the country region, setting (e.g., hospital), study period, risk group studied, number of subjects studied, and number of subjects positive to $\mathrm{HBsAg}$, or stated crude prevalence. Information related to age-specific outcome was also extracted. We took measures to detect and extract overlapping reports on the same study population. These measures included comparing the study period, sample size, centres where studies were performed, and author names.

The provinces of Turkey comprise 7 census-defined regions (bölge). For the purpose of this study, we pooled some regions together based on several factors such as geography, population size, and socioeconomic status. The following division of regions was done; Region A: Marmara and Aegean region; B: Black Sea, Central Anatolia and Mediterranean region; C: Eastern and southeastern region (Figure 1).

\section{Data extraction and data analysis}

Once a study was included, the following data were extracted and entered into tables: age group, study region, population type in terms of risk, total number of persons studied, number of persons positive for $\mathrm{HBsAg}$, and year of publication. Two of the authors (MT and FOÖ) checked all data used in the analysis. When disagreement arose, these were resolved by consensus. The unpublished studies (grey literature) were included in the analysis if they met the inclusion criteria. The unpublished material consists of abstracts presented at conferences and of personal communication with clinicians who designed the sero-epidemiology studies. The names and affiliations of the authors and the settings of the unpublished studies are listed in the Additional file 1: Appendix and referred to separately from the published literature.

\section{Age- and region-specific randomized community sampling}

The meta-analysis and data synthesis were done separately for the studies that included both region- and age-specific prevalence data, since these studies were mainly randomized community sampling. Most studies did not use a random sample from the population in each age group and sample or differed with respect to the year in which the sample was gathered. As a result, significant differences in the estimated prevalence may occur even within age groups and regions. To account for the differences among the included studies, a generalized linear mixed model was used to estimate the overall prevalence across all age groups and the 3 regions. In this model, we apply a logit link function and a binomial response distribution (similar to logistic regression) to predict the dependent variable, HBsAg positivity. The logit function is one of the most commonly used link functions for the binomial distribution. 


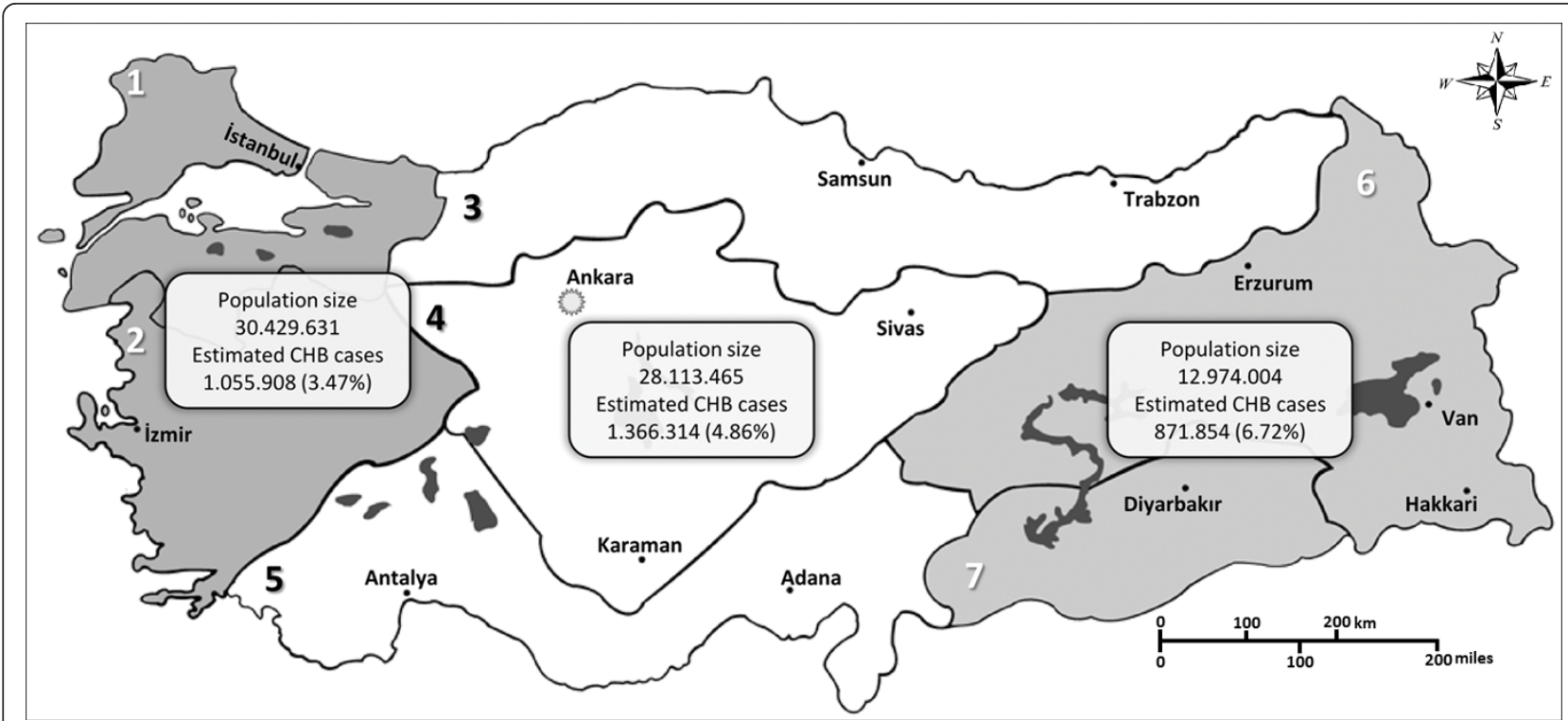

Figure 1 Map of Turkey according to regions, population size per region and the number of estimated CHB cases. Map of Turkey according to regions; 1: Marmara region, 2: Aegean region, 3: Black Sea region, 4: Inner Anatolia region, 5: Mediterranean region, 6: Eastern Anatolia region, 7: south-eastern Anatolia region. Regions with similar socioeconomic status and HBsAg seroprevalence are grouped as A (1 and 2), B (3, 4 and 5) and C (6 and 7).

The predictor variables of the model comprise a constant term, the categorical variables age and region, and a random intercept for each to account for unexplained variation in prevalence. The overall prevalence was estimated as the predicted value from a model that contained only a fixed intercept and a random intercept for the different studies. The model parameters were estimated using data from all studies and also separately, using only data from published studies. Model fit was evaluated from plots of the studentized residuals as a function of the linear predictor. The same method was used with region as a predictor to obtain region-specific estimates. These models were fitted with proc glimmix in SAS version 9.2 using adaptive Gaussian quadrature to approximate the log-likelihood function. From the data of these randomized community-sampling studies, we calculated the exact binomial 95\% confidence interval (CI) for the crude prevalence of each study. For such CI calculations, we made the assumption that each study used a random sample from the population.

\section{Other studies}

We calculated the weighted mean prevalence (WMP) to limit the bias caused by the heterogeneous nature of the reports. WMP was calculated as follows: WMP = $\sum \omega$ iprevi $/ \sum \omega \mathrm{i}$ where $\omega_{\mathrm{i}}=1 /\left[\operatorname{prev}_{\mathrm{i}}\left(1-\operatorname{prev}_{\mathrm{i}}\right) / \mathrm{N}_{\mathrm{i}}\right], \operatorname{prev}_{\mathrm{i}}$ is the fraction of (HBsAg positive patients) in study $i$, and $\mathrm{N}_{i}$ is the number of patients in study $i$. WMP is regarded as the most accurate method to estimate HBsAg prevalence when considering several reports
[8-10]. This method has proven to be reliable when combining a number of studies with inherent heterogeneity in sample and effects size [11]. This heterogeneity can be caused by a small difference in the way that patients are sampled in the population or by differences in the year of the study. The WMP was calculated for all data (published and unpublished); in addition, for the published data separate, two-sided Mann-Whitney tests were used to compare the prevalence distribution of published and unpublished studies.

\section{Results}

\section{General scope}

The results of the search strategy and final distribution of the studies are shown in Figure 2. The electronic search identified 254 papers, and manual reference checking identified an additional 84 references; we also received 1 unpublished dataset on military recruits. Out of the 197 studies that were reviewed, 136 studies were in Turkish, of which 19 were finally excluded. The list of references arranged by various criteria can be found in Tables 1, 2, 3 \&4. The systematic review identified 129 studies that provided prevalence estimates that were split into different subgroups.

\section{Age- and region-specific studies}

Thirty studies, of which 22 were published [12-33] and 8 unpublished (Additional file 1: Appendix; a-h), reported the age- and region-specific prevalence of hepatitis $B$. Both the age- and region-specific prevalence and the 


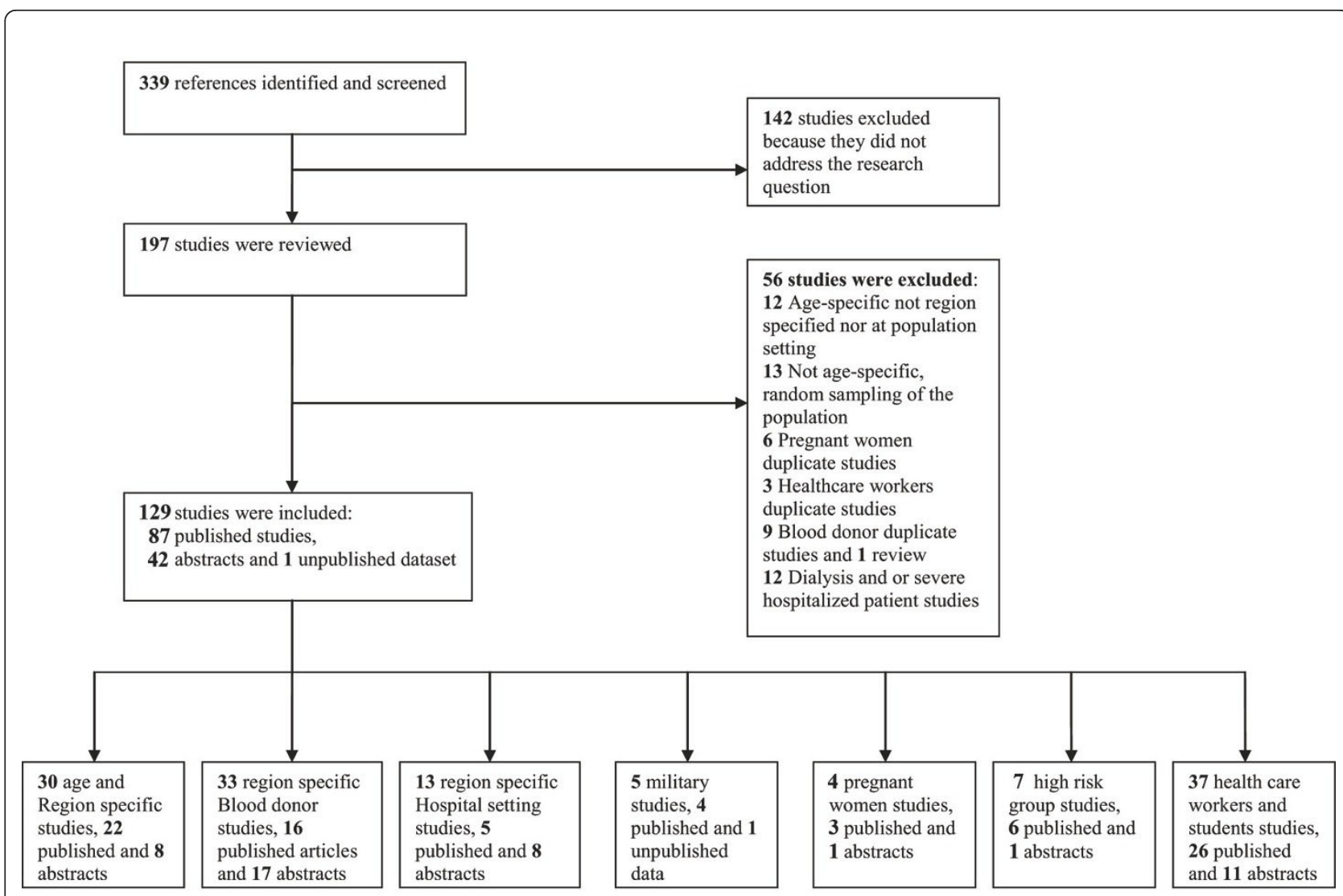

Figure 2 Flow diagram (Selection Strategy) of included studies.

overall population prevalence are shown in Table 1 . The overall age group prevalence for regions $\mathrm{A}, \mathrm{B}$, and $\mathrm{C}$ yields 3.52 (95\% CI: 1.92, 5.11), 4.95 (95\% CI: 3.06, 6.83), and 6.76 (95\% CI: 4.58, 8.93), respectively. Figure 3 shows the age group and region-specific curves of the pooled prevalence data. The estimated overall population prevalence was $4.57 \%$ (95\% CI 3.58, 5.76). The generalized linear mixed model was used to also estimate the prevalence using only the published data, which yielded a population prevalence of 5.10 (95\% CI: 4.22, 6.34). When this prevalence is extrapolated to the total population living in Turkey (71.5 million), the total number of $\mathrm{CHB}$ cases will be about 3.3 million (Figure $1)$. We included the year of study as a linear term in the model, which turned out to be insignificant with a $P$ value of 0.07 .

\section{Blood donors and hospital setting (non-donor population) by region}

A total of 33 blood donor studies, of which 16 were published [34-49] and 17 unpublished (Additional file 1: Appendix; i-y). A total of 13 hospital-setting studies were identified, of which 5 were published [50-54] and 8 unpublished (Additional file 1: Appendix; z-gg), separated into region-specific outcomes. The weighted mean prevalence (WMP) of HBsAg increases from region $\mathrm{A}$ to $\mathrm{C}$, from 2.53 to 4.25 , respectively. The same trend is seen in the weighted mean prevalence calculations in the hospital settings. For both study groups, there were fewer studies in region $\mathrm{C}$ than in the other 2 regions (Table 2).

\section{Pregnant women and military conscripts (age range, 17- 41 years)}

The results for pregnant women [55-57] and military recruits [58-61] are presented in Table 3. Military service is compulsory in Turkey for men between the ages of 17 and 39 years. The age range in the studies of pregnant women varied widely, from 17 to 41 years, which is equivalent in range to that of the military recruits, which is why we put these 2 study populations in the same table. From the results of the WMP, we observed a gender difference, which is $3.60 \%$ for military recruits and $1.70 \%$ for pregnant women.

\section{Health care workers and students}

As there have been vaccination policies for health care workers in Turkey since 1999, we separated the results 
Table 1 Age- and Region-Specific HBsAg Prevalence in Turkey, 1999-2009

\begin{tabular}{|c|c|c|c|c|c|c|c|c|c|c|c|c|c|c|c|}
\hline \multicolumn{4}{|c|}{ Age group } & \multicolumn{12}{|l|}{ Region $^{a}$} \\
\hline \multirow[t]{2}{*}{ (yr) } & \multicolumn{2}{|r|}{ A } & \multirow[b]{2}{*}{$\mathrm{n}$} & \multirow[b]{2}{*}{$\% H B s A g$} & \multirow[b]{2}{*}{$95 \% \mathrm{Cl}$} & \multicolumn{3}{|c|}{ B } & \multirow[b]{2}{*}{$\% \mathrm{HBsAg}$} & \multirow[b]{2}{*}{$95 \% \mathrm{Cl}$} & \multicolumn{3}{|c|}{ C } & \multirow[b]{2}{*}{$\% \mathrm{HBsAg}$} & \multirow[b]{2}{*}{$95 \% \mathrm{Cl}$} \\
\hline & Ref & $\mathrm{N}$ & & & & Ref & $\mathrm{N}$ & $\mathrm{n}$ & & & Ref & $\mathrm{N}$ & $n$ & & \\
\hline \multirow[t]{7}{*}{$0-14$} & a & 420 & 14 & 3.33 & $1.83,5.52$ & {$[12]$} & 460 & 7 & 1.52 & $0.61,3.11$ & [13] & 402 & 13 & 3.23 & $1.73,5.47$ \\
\hline & $b$ & 249 & 11 & 4.41 & $2.22,7.76$ & {$[14]$} & 875 & 26 & 2.97 & $1.95,4.32$ & c & 158 & 9 & 5.70 & $2.64,10.54$ \\
\hline & $d$ & 230 & 6 & 2.60 & $0.96,5.59$ & [15] & 1131 & 80 & 7.07 & $5.64,8.73$ & {$[16]$} & 853 & 84 & 9.84 & $7.93,12.04$ \\
\hline & e & 1952 & 67 & 3.43 & $2.66,4.34$ & $f$ & 1278 & 22 & 1.72 & 1.08. 2.59 & {$[17]$} & 700 & 29 & 4.14 & $2.79,5.90$ \\
\hline & [18] & 176 & 3 & 1.70 & $0.35,4.90$ & [19] & 420 & 13 & 3.10 & $1.66,5.23$ & {$[20]$} & 74 & 6 & 8.10 & $3.03,16.81$ \\
\hline & [21] & 6788 & 84 & 1.24 & $0.99,1.53$ & g & 100 & 2 & 2.00 & $0.24,7.03$ & {$[22]$} & 802 & 22 & 2.71 & $2.45,2.97$ \\
\hline & [23] & 423 & 8 & 1.89 & $0.82,3.69$ & [24] & 454 & 4 & 0.88 & $0.24,2.24$ & & & & & \\
\hline Total & & 10238 & 193 & 1.88 & $1.63,2.16$ & & 4718 & 154 & 3.26 & $2.77,3.81$ & & 2989 & 163 & 5.45 & $4.66,6.32$ \\
\hline \multicolumn{2}{|c|}{ Total overall ${ }^{\mathbf{b}}$} & 17945 & 510 & 3.23 & $2.96,3.53$ & & & & & & & & & & \\
\hline \multirow[t]{7}{*}{$15-24$} & {$[25]$} & 129 & 6 & 4.65 & $1.72,9.85$ & {$[12]$} & 1058 & 43 & 4.06 & $2.96,5.44$ & [13] & 183 & 7 & 3.82 & $1.55,7.72$ \\
\hline & [18] & 440 & 46 & 10.45 & $7.75,13.70$ & {$[26]$} & 238 & 12 & 5.04 & $2.63,8.64$ & [27] & 213 & 46 & 21.60 & $16.27,27-73$ \\
\hline & [21] & 2822 & 178 & 6.31 & $5.44,7.27$ & $f$ & 2431 & 114 & 4.69 & $3.88,5.60$ & {$[20]$} & 187 & 29 & 15.50 & $10.63,21.50$ \\
\hline & {$[28]$} & 7237 & 98 & 1.35 & $1.10,1.65$ & [29] & 350 & 11 & 3.14 & $1.58,5.55$ & $\mathrm{~h}$ & 96 & 3 & 3.21 & $0.65,8.86$ \\
\hline & & & & & & {$[30]$} & 155 & 20 & 13.00 & $8.06,19.22$ & & & & & \\
\hline & & & & & & {$[24]$} & 193 & 7 & 3.62 & $1.47,7.32$ & & & & & \\
\hline & & & & & & {$[31]$} & 340 & 22 & 6.47 & $4.09,9.63$ & & & & & \\
\hline \multicolumn{2}{|l|}{ Total } & 10628 & 328 & 3.08 & $2.76,3.43$ & & 4765 & 229 & 4.81 & $4.21,5.45$ & & 679 & 85 & 12.51 & $10.12,15.24$ \\
\hline Total & & 15636 & 617 & 5.77 & $5.26,6.32$ & & & & & & & & & & \\
\hline $25-34$ & [18] & 226 & 18 & 7.97 & $4.79,12.29$ & {$[12]$} & 833 & 53 & 6.36 & $4.80,8.24$ & [13] & 219 & 19 & 8.67 & $5.30,13.21$ \\
\hline & [21] & 3674 & 235 & 6.40 & $5.62,7.24$ & $f$ & 2431 & 114 & 4.69 & $3.88,5.60$ & {$[27]$} & 324 & 60 & 18.50 & $14.43,23.18$ \\
\hline & & & & & & {$[24]$} & 193 & 7 & 3.62 & $1.47,7.33$ & $h$ & 435 & 26 & 5.98 & $3.94,8.63$ \\
\hline & & & & & & {$[31]$} & 238 & 12 & 5.04 & $2.63,8.64$ & & & & & \\
\hline Total & & 3900 & 253 & 6.49 & $5.73,7.30$ & & 3695 & 186 & 5.03 & $4.35,5.78$ & & 978 & 105 & 10.73 & $8.86,12.85$ \\
\hline Total & & 7950 & 506 & 7.08 & $6.47-7.73$ & & & & & & & & & & \\
\hline $35-44$ & [18] & 142 & 7 & 4.93 & $2.00,9.89$ & [32] & 85 & 10 & 11.76 & $5.79,20.57$ & [13] & 17 & 2 & 11.77 & $1.46,36.44$ \\
\hline & [21] & 4323 & 249 & 5.76 & $5.08,6.49$ & [12] & 741 & 71 & 9.58 & $7.55,11.93$ & [27] & 271 & 41 & 15.13 & $11.08,19.96$ \\
\hline & & & & & & $f$ & 3208 & 170 & 5.30 & $4.55,6.13$ & $\mathrm{~h}$ & 555 & 38 & 6.84 & $4.90,9.28$ \\
\hline & & & & & & [24] & 193 & 7 & 3.63 & $1.47,7.33$ & & & & & \\
\hline & & & & & & {$[31]$} & 173 & 7 & 4.05 & $1.64,8.16$ & & & & & \\
\hline Total & & 4465 & 256 & 5.73 & $5.07,6.45$ & & 4400 & 265 & 6.02 & $5.33,6.76$ & & 843 & 81 & 9.60 & $7.70,11.80$ \\
\hline Total & & 8980 & 557 & 6.93 & $6.32,7.60$ & & & & & & & & & & \\
\hline $45-54$ & [18] & 85 & 7 & 8.23 & $3.37,16.23$ & [32] & 55 & 5 & 9.09 & $3.02,19.95$ & [13] & 17 & 2 & 11.76 & $1.46,36.44$ \\
\hline & [21] & 2170 & 100 & 4.60 & $3.76,5.58$ & $f$ & 3208 & 170 & 5.30 & $4.55,6.13$ & {$[27]$} & 244 & 29 & 11.88 & $8.10,16.62$ \\
\hline & & & & & & {$[12]$} & 288 & 27 & 9.37 & $6.27,13.35$ & $\mathrm{~h}$ & 469 & 34 & 7.24 & $5.07,9.98$ \\
\hline & & & & & & [24] & 346 & 12 & 3.47 & $1.80,5.98$ & & & & & \\
\hline & & & & & & {$[31]$} & 143 & 5 & 3.50 & $1.14,7.97$ & & & & & \\
\hline Total & & 2255 & 107 & 4.75 & $3.90,5.70$ & & 4040 & 219 & 5.42 & $4.74,6.16$ & & 730 & 65 & 8.90 & $6.94,11.20$ \\
\hline Total & & 6468 & 357 & 6.13 & $5.48,6.85$ & & & & & & & & & & \\
\hline $55-64$ & [18] & 32 & 0 & 0 & 0 & $f$ & 4031 & 129 & 3.20 & $2.68,3.79$ & [13] & 17 & 2 & 11.76 & $1.46,36.44$ \\
\hline & [21] & 631 & 32 & 5.07 & $3.49,7.08$ & {$[12]$} & 56 & 1 & 1.78 & $0.05,9.55$ & [27] & 125 & 15 & 12.00 & $6.87,19.01$ \\
\hline & & & & & & {$[24]$} & 346 & 12 & 3.47 & $1.80,5.98$ & $h$ & 463 & 30 & 6.48 & $4.41,9.12$ \\
\hline & & & & & & {$[31]$} & 118 & 11 & 9.32 & $4.75,16.06$ & & & & & \\
\hline Total & & 663 & 32 & 4.83 & $3.32,6.74$ & & 4551 & 153 & 3.36 & $2.85,3.93$ & & 605 & 47 & 7.77 & $5.76,10.19$ \\
\hline Total & & 5238 & 191 & 5.03 & $4.29,5.89$ & & & & & & & & & & \\
\hline $65+$ & [33] & 165 & 15 & 9.09 & $5.17,14.55$ & $f$ & 204 & 5 & 2.45 & $0.80,5.63$ & [13] & 17 & 2 & 11.76 & $1.46,36.44$ \\
\hline
\end{tabular}


Table 1 Age- and Region-Specific HBsAg Prevalence in Turkey, 1999-2009 (Continued)

\begin{tabular}{|c|c|c|c|c|c|c|c|c|c|c|c|c|c|c|}
\hline [18] & 89 & 2 & 2.24 & $0.27,7.88$ & {$[24]$} & 714 & 29 & 4.06 & $2.74,5.78$ & {$[27]$} & 127 & 10 & 7.87 & $3.84,14.00$ \\
\hline$[21]$ & 1115 & 35 & 3.14 & $2.20,4.34$ & {$[31]$} & 83 & 3 & 3.61 & $0.75,10.20$ & $\mathrm{~h}$ & 1140 & 28 & 2.45 & $1.64,3.53$ \\
\hline$\overline{T o t a l}$ & 1369 & 52 & 3.80 & $2.84,4.95$ & & 1001 & 37 & 3.70 & $2.61,5.06$ & & 1284 & 40 & 3.11 & $2.23,4.21$ \\
\hline Total overall ${ }^{\mathbf{b}}$ & 2431 & 98 & 3.52 & $2.95-4.19$ & & & & & & & & & & \\
\hline Overall Prevalenc & & & 4.57 & $3.58,5.76$ & & & & & & & & & & \\
\hline
\end{tabular}

into 2 sections. We compared the prevalence rates of studies between 1990 and 1999, and 2000 and 2009 for both health care workers (HCW) [62-83] and health care students (HCS) [84-87]. Table 4 shows the decrease in prevalence within the 10 -year periods before and after vaccination for $\mathrm{HCW}$ and $\mathrm{HCS}$; the WMP decreased from 3.34 to 2.29 , and from 3.31 to 2.08 , respectively.

\section{High-risk groups}

To show the prevalence among those at high risk for hepatitis B, we present the results for the following groups: high-risk occupations; prison inmates; and female sex workers. The high-risk occupation group consisted of studies among hairdressers, butchers, garbage men, and coffee house workers. There were 2 studies $[88,89]$ that were eligible and used to calculate the WMP, which was 7.63. There were 3 prison inmate studies, which were all unpublished (uu-ww) and yielded a WMP of 6.73. Two studies, of which 1 was published [90] and the other unpublished (Additional file 1: Appendix; xx), were analyzed for the female sex worker (FSW) group, which yielded a WMP of 7.00.

\section{Discussion}

\section{Age- and region-specific prevalence estimates}

The age- and region-specific analysis relied primarily on community-based studies from various regions. The results yielded a marked difference in the overall regionspecific estimated prevalence, which ranged from 3.52 to 6.76. The age-specific prevalence also varied greatly between the lowest prevalence in the age group of 0-14 years (2.84) and the highest prevalence, age group 25-34 years (6.36). The overall country-specific prevalence was 4.57 , retrieved from the meta-analysis, across all regions and age groups.

\section{Region-specific, HBsAg-prevalence estimates for different} sample populations

Population sample groups such as blood donors have been used as a convenient means to estimate the country-specific prevalence of HBV [4]. Since blood donation in Turkey is voluntary and the predonation eligibility assessment is quite strict, a healthy donor effect prevails in this sample population, and likely leads to an underestimation of the true HBV prevalence. Blood donors in this case cannot be representative of an entire population. Our results showed a difference in the region-specific estimates, where the weighted mean prevalence (WMP) ranges from 2.53 to 4.25. When compared with the age- and region-specific outcomes, the results in this sample population are in the low range, whereas the results in the hospital-setting studies are in the high range. Thus, results based on blood donors and from hospital settings should be interpreted with caution.

Table 2 Weighted mean region-specific HBsAg prevalence in blood donors and hospital settings

\begin{tabular}{llccccccc}
\hline Study group & \multicolumn{7}{c}{ \%HBsAg prevalence (range) } \\
\hline Category & no.studies & $\mathbf{N}$ & $\mathbf{n}$ & Region* & Weighted mean all data & Weighted mean published data & $\boldsymbol{P}$ value & References \\
\hline Blood donors & 13 & 658662 & 16788 & $\mathrm{~A}$ & $2.53(1.10,8.70)$ & $2.33(1.70,2.75)$ & 0.51 & {$[34-40](\mathrm{i}-\mathrm{n})$} \\
\hline & 16 & 223949 & 6389 & $\mathrm{~B}$ & $2.68(1.70,4.22)$ & $3.44(2.60,4.20)$ & 0.14 & {$[41-46](\mathrm{o}-\mathrm{x})$} \\
\hline & 4 & 149918 & 6675 & $\mathrm{C}$ & $4.25(1.70,4.90)$ & $4.45(2.92,4.90)$ & 0.50 & {$[47-49](\mathrm{y})$} \\
\hline Hospitalt & 5 & 37497 & 2977 & $\mathrm{~A}$ & $3.40(1.30,13.80)$ & $1.30(0.90,1.63)$ & 0.40 & {$[50](\mathrm{z}-\mathrm{cc})$} \\
\hline & 6 & 100343 & 7781 & $\mathrm{~B}$ & $7.15(2.90,13.60)$ & $5.73(2.90,13.60)$ & 1.00 & {$[51,52](\mathrm{dd}-\mathrm{gg})$} \\
\hline & 2 & 28392 & 6037 & $\mathrm{C}$ & - & $10.88(9.60,21.30)$ & - & {$[53,54]$} \\
\hline
\end{tabular}

Abbreviations: $N$ number of subjects, $n$ number of cases

$P$ value calculated by the two-sided Mann-Whitney test (difference in prevalence of all data and only published data)

* Region A: Marmara and Aegean, B: Black Sea, Central Anatolia and Mediterranean, C: Eastern and South-eastern

† Studies based in hospital settings on non-liver-related conditions 
Table 3 Weighted mean HBsAg prevalence in the military and in pregnant women

\begin{tabular}{llcccccc}
\hline Study group & \multicolumn{7}{c}{ \%HBsAg prevalence (range) } \\
\hline Category & no.studies & $\mathbf{N}$ & $\mathbf{n}$ & Weighted mean all data & Weighted mean published data & $\boldsymbol{P}$ value & Reference \\
\hline Pregnant Women & 4 & 6215 & 137 & $1.70(1.31,9.30)$ & $1.60(1.31,3.50)$ & 0.50 & {$[55-57](\mathrm{hh})$} \\
\hline Military & 5 & 90914 & 3539 & $3.60(2.16,9.80)$ & $3.83(2.16,9.80)$ & 0.80 & {$[58-61]($ ii) } \\
\hline$P$
\end{tabular}

$P$ value calculated by the two-sided Mann-Whitney test (difference in prevalence of all data and only published data)

Another convenient sample of population-based studies is the military conscripts. Military service prevalence studies provide good estimates for the general population of men between the ages of 17 and 41, while pregnant women studies represent the comparable female population of the same age range. Both these sample groups are more representative than blood donors and those from hospital settings. Although screening for HBV in pregnant women is not yet routine in Turkey, nonetheless pregnant women are likely to be tested during their pregnancies, either for research or for health purposes. Our WMP results comparing these 2 groups suggest that HBV is more prevalent among males.

\section{Strengths and limitations}

The main strength of this systematic review is that it includes all available Turkish studies, including both published and unpublished abstracts (grey literature), to overcome publication bias, and in particular language bias. Due to the paucity of studies from Turkey on hepatitis B in English, this review provides a wealth of information that would not be accessible to scientists and policy makers from other countries in the world. We used an innovative approach to fit generalized linear mixed models in estimating the prevalence from various studies. Including the year of the study as a linear term in the model showed no significant trend in prevalence over time. Since prevalence is assumed to be not constant, this could be a limitation of the model. Another limitation may be the dependence on the quality of the original reports. The strength of the study may also be a weakness in that conventional wisdom points towards an inverse correlation between quantity and quality. Despite this limitation, we believe that the study provides useful data on the epidemiology of hepatitis B in Turkey for health planning strategies, both in Turkey as well as in the Turkish migrant population. We suggest that researchers who are preparing observational research, such as sero-survey studies, implement the STROBE guidelines [91] to ensure a clear presentation of what was planned, done, and found in such a study.

\section{Comparing the eras of pre-vaccination and post- vaccination}

Since the implementation of universal vaccination in 1998 of all children and risk groups, a decline in prevalence has been observed [4]. Although the current study does not address this issue directly, the availability of age-specific prevalence rates in the postvaccination era enables us to make meaningful comparisons in children from studies in the prevaccination era. In this context, Kanra et al. [92] studied the prevalence in all regions of Turkey among children before the vaccination policy was implemented. Their finding of an overall country prevalence of 5.90 among 0 -15-year-olds compares favourably to the current overall country prevalence rate of 2.84 reported in this study for the same age group. The impact of vaccination was also assessed in health care workers and health care students. The WMP estimates in the postvaccination studies show a decline, which could be explained by the impact of the vaccination campaign or, as a secondary explanation, that HBV has the tendency to decrease over the years. A study from the United States shows patterns in the success of vaccination application to health care workers [93].

\section{Implications for health policy}

Nearly every country with a large or diverse geographic area is expected to have regional differences in HBV

Table 4 Weighted mean HBsAg prevalence rates of health care workers and students before and after vaccination

\begin{tabular}{llcccccccc}
\hline Risk-group & \multicolumn{7}{c}{ \%HBsAg prevalence (range) } \\
\hline Category & year & no.studies & $\mathbf{N}$ & $\mathbf{n}$ & Weighted mean all data & Weighted mean published data & $\boldsymbol{P}$ value & Reference \\
\hline HCW & $1989-1999$ & 15 & 4147 & 191 & $3.34(1.60,8.60)$ & $3.86(1.90,8.00)$ & 0.97 & {$[62-74](\mathrm{jj}-\mathrm{kk})$} \\
\hline HCW & $2000-2009$ & 15 & 5146 & 137 & $2.29(1.40,5.90)$ & $2.35(1.40,5.90)$ & 0.60 & {$[75-83](\mathrm{II-qq})$} \\
\hline HCS & $1989-1999$ & 4 & 1022 & 39 & $3.31(2.40,8.60)$ & $3.42(2.60,8.60)$ & 0.50 & {$[84-86](\mathrm{rr})$} \\
\hline HCS & $2000-2009$ & 3 & 438 & 8 & $2.08(1.00-2.40)$ & $2.00(0.20,3.70)$ & 1.00 & {$[87](\mathrm{ss}-\mathrm{tt})$} \\
\hline
\end{tabular}

Abbreviations: $N$ number of subjects, $n$ number of cases, HCW health care worker, HCS health care student

$P$ value calculated by the two-sided Mann-Whitney test (difference in prevalence of all data and only published data). 
prevalence, and the extent of the geographic variation can be very important. The large regional differences in prevalence in Turkey are mainly due to differences in socioeconomic status, lifestyles, infrastructure, and access to health services. In the eastern and south-eastern regions (treated as 1 region) of Turkey, all reasons mentioned above apply in a negative way, though the latest years have witnessed much improvement in the socioeconomic, and hygienic and sanitary conditions in this region and in Turkey in general. This region also lags behind in coverage of HBV vaccination. Although only $18 \%$ of the total population live in this area, the estimated number of $\mathrm{CHB}$ cases is almost equal to that of the other regions, which have higher population numbers (see Figure 1). A substantial migration has taken place from the southeast and east to the west of the country, mainly for economic reasons. The scarcity of reports from southeast and east Turkey, despite the magnitude of the $\mathrm{CHB}$ problem, may be an indirect reflection of the health infrastructure of this region. The region-specific data in this study could stimulate a broad-based prevention and control campaign whereby hepatitis $B$ vaccines and/or treatment and monitoring could be targeted to high-priority regions. Turkey has a large proportion of young people (age 14-30 years, which is more than $66 \%$ of the total population). It is a dynamic society with a growing number of educated people; further, the proportion of the population living in cities has increased dramatically in recent decades and now accounts for approximately $70 \%$ of the national total. With an average prevalence of 3.50 in young people age $0-24$ years, hepatitis $B$ remains a significant public health problem in Turkey.

Another important facet of the data in this study is linked to disease awareness, although this is certainly not specific to Turkey, since CHB patients in general are mostly asymptomatic. With an overall HBV prevalence of 4.57, the estimated number of HBV carriers in Turkey is 3.3 million. Even a very conservative assessment means that $10 \%$ of the carriers would need treatment, yielding 330,000 chronic HBV cases eligible for treatment in Turkey alone. We recently estimated that treatment of $\mathrm{CHB}$ patients with active disease with a low-resistance profile drug could reduce mortality related to liver disease in this group by $80 \%$ [94]. It needs to be stressed that in Turkey, viral hepatitis treatment is fully reimbursed through the national insurance system. According to net sold medication counts per

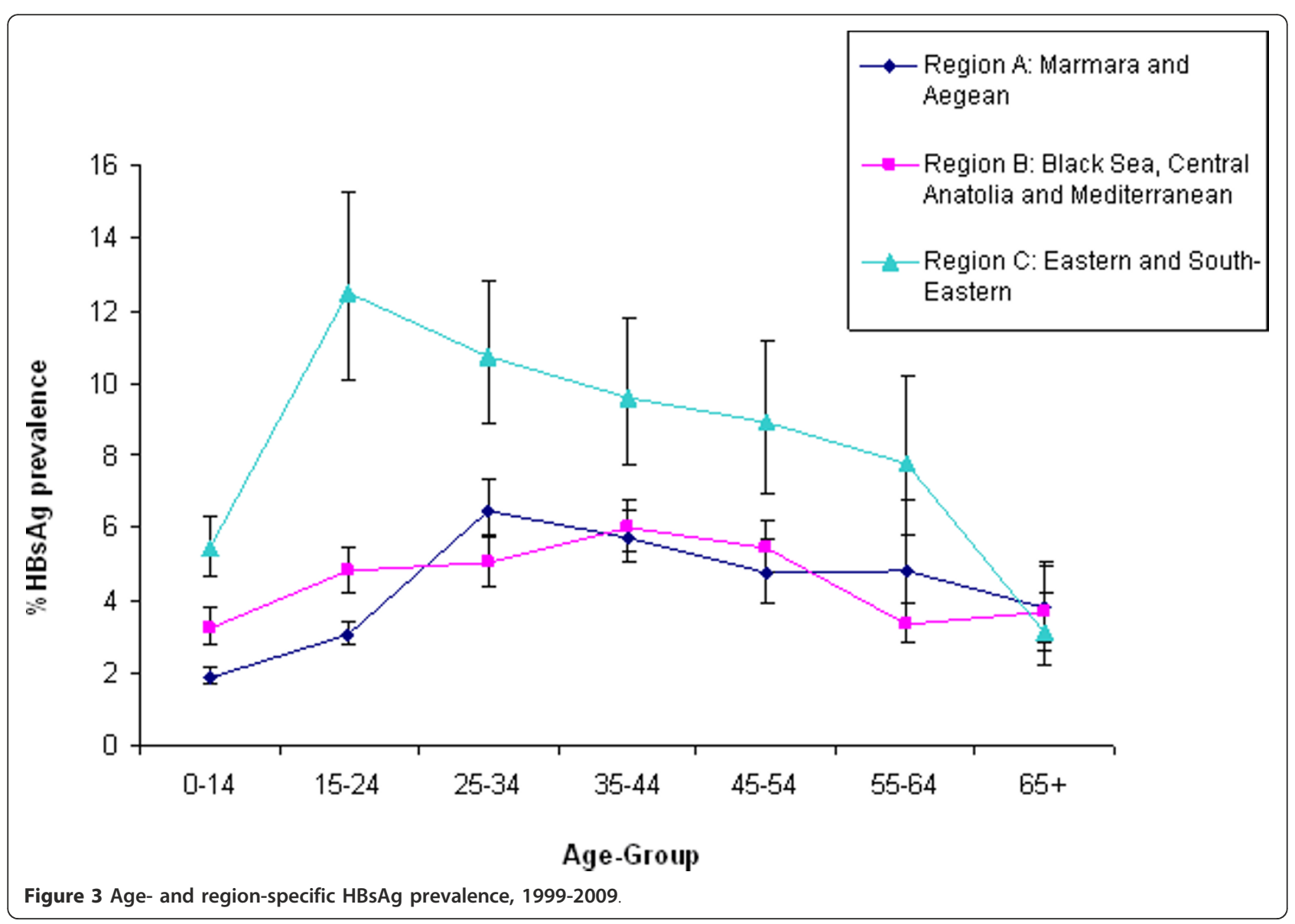


year, it was calculated that no more than $10 \%$ of eligible patients receive active treatment [95], indicating a massive shortcoming in ensuring prolonged life and even life-saving treatments. Chronic HBV infection is a lifelong illness. It can cause serious, life-threatening complications, such as cirrhosis, liver cancer, or liver failure. Most liver transplants in Turkey are attributed to liver disease from chronic HBV. A viral hepatitis national plan should be designed that will lower hepatitis prevalence, increase research, and accelerate access to care for the chronically infected. Testing for immunization coverage should be instituted at the state and regional level. Potential next steps would be to improve epidemiologic surveillance systems, develop a hepatitis registry, and implement serosurveys in order to produce reliable data to guide prevention and control measures and to monitor the impact of preventive strategies.

The importance of our study is certainly not confined to the borders of Turkey. Recent evidence suggests that the overall decline in HBV prevalence in the last decade in industrialized countries of Europe appears to have reached a plateau. The most likely reason why the progressive decline in HBV prevalence has come to a halt is migration from endemic areas $[96,97]$. There are currently more than 3 million immigrants, descendants of immigrants, and naturalized citizens and political refugees from Turkey in Western Europe, representing the largest immigrant group in the European Union. The public health implications of the current study thus go far beyond the border of Turkey.

\section{Conclusions}

Despite the availability of a safe and effective vaccine for more than 20 years and because of its asymptomatic nature, $\mathrm{CHB}$ remains a serious health problem. As this study shows, the estimates of age- and region-specific prevalence reflect the burden of existing $\mathrm{CHB}$ cases in Turkey. Knowing the diversity in prevalence of $\mathrm{CHB}$ in Turkey, public health organizations should turn their attention, means, and actions increasingly to the areas and groups that are lagging behind.

\section{Additional material}

Additional file 1: Appendix: grey literature (DOC $27 \mathrm{~kb}$ )

\section{List of abbreviations}

Cl: Confidence interval; CHB: Chronic hepatitis B; EU: European Union; HBsAg: Hepatitis B surface antigen; HBV: Hepatitis B virus; HCC: Hepatocellular carcinoma; HCS: Health care worker; HCW: Health care student; WHO: World Health Organization; WMP: Weighted mean prevalence.

Acknowledgements

None
Source of funding

This work was supported by the European Association for the Study of the Liver (EASL) Dame Sheila Sherlock short-term fellowship awarded to Mehlika Toy.

\section{Author details}

${ }^{1}$ Department of Public Health, Erasmus MC, University Medical Center Rotterdam, Dr. Molewaterplein 50,3000 CA Rotterdam, the Netherlands. ${ }^{2}$ LiverDoc, Rotterdam, the Netherlands. ${ }^{3}$ Department of Gastroenterology, Yuksek Ihtisas Hospital, Kızılay Sk. 06100 Sinhıye, Ankara, Turkey. ${ }^{4}$ Department of Public Health Medicine, School of Public Health, University of Bielefeld, Bielefeld, Northrhine-Westphalia, Germany. ${ }^{5}$ Institute of Hepatology, Ankara University, Cemal Gursel caddesi, Ankara, Turkey. ${ }^{6}$ Department of Gastroenterology and Hepatology, Erasmus MC, University Medical Center Rotterdam, Dr. Molewaterplein 50,3000 CA Rotterdam, the Netherlands. ${ }^{7}$ Department of Gastroenterology, School of Medicine, Ankara University, Cemal Gursel caddesi, Ankara, Turkey.

\section{Authors' contributions}

MT designed the study, collected the data, and wrote the manuscript. FOÖ participated in data collection, literature review, and writing of the manuscript. TW participated in the literature review and prepared the Tables and Figures. AMB supervised the literature review. SWS assisted with the overall study design and the writing of the manuscript. GJB built the generalized linear mixed models. JvR supervised the statistical analysis and helped in preparing Tables and Figures. JHR supervised the public health aspects of the study and assisted in the preparation of the manuscript. CY was responsible for the overall supervision of the study. All authors have read and approved the manuscript.

\section{Competing interests}

The authors declare that they have no competing interests.

Received: 20 April 2011 Accepted: 12 December 2011 Published: 12 December 2011

\section{References}

1. Lavanchy D: Hepatitis B virus epidemiology, disease burden, treatment, and current and emerging prevention and control measures. J Viral Hepatitis 2004, 11(2):97-107.

2. Mahoney FJ: Update on diagnosis, management, and prevention of hepatitis B virus infection. Clin Microbiol Rev 1999, 12(2):351-366.

3. Mistik R: The epidemiology of viral hepatitis in Turkey: analysis of published data. In Viral Hepatit. Volume 1.. 1 edition. Edited by: Tabak F. Istanbul:Viral Hepatit Savasim Dernegi; 2007:10-50.

4. Gurol E, Saban C, Oral O, Cigdem A, Armagan A: Trends in hepatitis B and hepatitis $C$ virus among blood donors over 16 years in Turkey. Eur J Epidemiol 2006, 21:299-305.

5. Üner A, Kirimi E, Tuncer I, Ceylan A, Türkdogan M, Abuhandan M: Seroepidemiology of hepatitis $B$ virus infection in children in the Eastern Anatolia. East J Med 2001, 6(2):40-42.

6. Veldhuijzen IK, Toy M, Hahne SJ, De Wit GA, Schalm SW, de Man RA, Richardus JH: Screening and early treatment of migrants for chronic hepatitis B virus infection is cost-effective. Gastroenterology 2010, 138(2):522-530.

7. Stroup DF, Berlin JA, Morton SC, Olkin I, Williamson GD, Rennie D, Moher D, Becker BJ, Sipe TA, Thacker SB: Meta-analysis of observational studies in epidemiology: a proposal for reporting Meta-analysis Of observational studies in epidemiology (MOOSE) group. Jama 2000, 283(15):2008-2012.

8. Mohan A, Chandra S, Agarwal D, Guleria R, Broor S, Gaur B, Pandey RM: Prevalence of viral infection detected by PCR and RT-PCR in patients with acute exacerbation of COPD: a systematic review. Respirology 2010, 15(3):536-542.

9. Chiquete $E$, Panduro $A$ : Low prevalence of anti-hepatitis $C$ virus antibodies in Mexico: a systematic review. Intervirology 2007, 50(1):1-8.

10. Roman S, Panduro A, Aguilar-Gutierrez Y, Maldonado M, VazquezVandyck M, Martinez-Lopez E, Ruiz-Madrigal B, Hernandez-Nazara Z: A low steady HBsAg seroprevalence is associated with a low incidence of HBVrelated liver cirrhosis and hepatocellular carcinoma in Mexico: a systematic review. Hepatol Int 2009, 3(2):343-355. 
11. Bradburn M, Deeks J, Altman D: Metan: an alternative meta analysis command. Stata Tech Bull 1998, 44:4-15.

12. Kurt H, Battal İ, Memikoğlu O, Yeşilkaya A, Tekeli E: Ankara Bölgesinde Sağlıklı Bireylerde HAV, HBV, ve HCV seroprevalansının yaş ve cinsiyetlere göre dağılımı (Age and gender specific distribution HBV and HCV seroprevalence in healthy individuals in Ankara). Viral Hepatitis $J$ 2003, 8:88-96

13. Emiroğlu H, Kesecik $M$, Oğuz S, Öztürk M, Nazlıgül $Y$, Altunay H: Şırnaktaki asker ve sivillerde asemptomatik HBV taşıyıcılığı prevalansı (Prevalance of inactive HBV disease in soldiers and civilians in Şırnak). Viral Hepatitis $J$ 2000, 6(1):18-20.

14. Özüyürek H, Kaya D, Şimşek E: Düzce Illkokullarında hepatit B prevalansı (Hepatitis B prevalence in primary schools in Duzce). Viral Hepatitis J 2001, 7(2):333-334

15. Bör $O$, Us T, Akgün $N$, Akgün $Y$ : Çocuklarda hepatit $A, B$ ve $C$ virusları seromarker sonuçları (Seroprevalence of hepatitis A, B and C in children). Viral Hepatitis J 2000, 6(2):102-104.

16. Ceylan A, Abuhandan M, Türkdoğan M, Öner A, Berktas M: Van yöresindeki çocuklarda hepatit B infeksiyonu prevalansı (Prevalance of hepatitis B infeciton in children in Van). Viral Hepatitis J 2000, 6(1):21-23.

17. Degertekin H, Tuzcu A, Yalcin K: Horizontal transmission of HBV infection among students in Turkey. Public Health 2000, 114(5):411-412.

18. Pahsa A, Üzsoy M, Altunay H, Koçak N, Ekren Y, Çavuşlu S: İstanbulda Hepatit B ce C seroprevalansı (Seroprevalance of hepatitis B and C in İstanbul). Gülhane Med J 1999, 41:325-330.

19. Sönmez E, Kutlu O, Bayındır Y: 0-6 yaş grubunda hepatit $A, B, C, D$ virus enfeksiyonlarının prevalansının saptanması (Detection of seroprevalance of hepatitis A, B, C and D infections in 0-6 years old). Viral Hepatitis $J$ 2000, 6(1):12-17.

20. Ertekin V, Selimoglu MA, Altinkaynak S: Sero-epidemiology of hepatitis B infection in an urban paediatric population in Turkey. Public Health 2003, 117(1):49-53.

21. Tansuğ Ş, Düzgünsıvacı E, Ünal Z, Gürel H: Hepatit B enfeksiyonunun seroepidemiolojik araştırılması (Seroepidemiology of Hepatitis B). Viral Hepatitis J 1999, 5(2):96-109.

22. Dikici B, Uzun H, Gozu A, Fidan M: Prevalence of hepatitis B infection among schoolchildren in Southeast Turkey. Turk J Med Sci 2009, 39(2):289-293.

23. Hizel S, Sanli C, Saygi S, Tombakoglu M, Kaygusuz S, Apan T: Kirikkale ilinde cocuklarda hepatit $A, B$ ve $C$ virus seroprevalansi (Hepatitis A, B and C virus prevalence among children in kirklareli province). Viral hepatiti dergisi 2004, 9(3):156-161

24. Ocak S, Kaya H, Cetin M, Inandi T: Antakya'da preoperatif hastalarda hepatiti A ve B seropozitifligi, yas ve cinsiyete gore dagilim (Hepatitis A and $B$ positivity among pre-operative patients according to age and gender in Antakya). Viral hepatit dergisi 2005, 10(3):169-175.

25. Polat $A$, Köseoğlu O, Kaptanoğlu B: Sanayide çalışan adolesanlarda viral hepatit $A, B$ ve $C$ seroprevalansı (Seroepidemiology of hepatitis $A, B$ and $C$ in adolescents working in industry). Turk J Infect 2000, 14:331-333.

26. Köseoğlu Ö, Bayraktar M, Güngör N, Darka Ö, Günalp A: Adolesan yaş grubu erkek öğrencilerde hepatit B seroepidemiyolojisi ve ilişkili risk faktörleri (Seroepdiemiology of hepatitis B and related risk factors in adolescent male students). Viral Hepatitis J 2003, , 9: 82-88.

27. Dursun M, Ertem M, Yilmaz S, Saka G, Ozekinci T, Simsek Z: Prevalence of hepatitis $B$ infection in the southeastern region of Turkey: comparison of risk factors for HBV infection in rural and urban areas. Jpn J Infect Dis 2005, 58:15-19.

28. Karaca B, Tarakci H, Tumer E: Izmir Ili Lise ogrencilerinde $\mathrm{HbsAg}$ seroprevalansi (HBsAg prevalence among highschool students in Izmir). Viral hepatiti dergisi 2007, 12(2):91-94.

29. Borazan A, Bayraktaroglu T, Polat H, Tek B, Findik D, Ecirli S: Selcuk universitesi ogrencilerinde $\mathrm{HbsAg}$ ve Anti-HBs prevalansi (HBsAg and anti-HBs prevalence among Selcuk university students). Viral hepatit dergisi 2003, 8(2):107-110.

30. Koseoglu O, Gungor N, Darka O, Gunalp A: Adolesan yas grubu erkek ogrencilerde hepatit B seroepidemiolojisi ve iliskili risk faktorleri (Hepatitis B seropepidemiology and risk factors among adolescent male students). Viral hepatit dergisi 2004, 9(2):82-88.

31. Yildirim B, Barut S, Bulut Y, Yenisehirli G: Seroprevalence of hepatitis B and $C$ viruses in the providence of Tokat in the black sea region of Turkey: $A$ population-based study. Turk J Gastroenterol 2009, 20(1):27-30.
32. Barak $S$, Yoldaşan $E$, Kılıç $B$ : Adana ili yarıkırsal alanda yaşayan 10 yaş üzeri kişilerde HBsAg ve anti-HCV prevalansı (HBsAg and anti-HC V seroprevalence in people older tahn 10 years old in suburban area in Adana). Turkish J Infect 2002, 16:133-140.

33. Altindis $M$, Sener M: Huzur evinde kalanlarda ve personelinde HBV enfeksiyonu taramasi (HBV infection screening in the elderly home habitants and personel). Viral Hepatit Dergisi 2001, , 2: 321-323.

34. Altındiş $M$, Koçoğlu F: Afyon Bölgesi kan dönorlerinde viral enfeksiyon etkenlerinin araştırılması.(Prevalence of viral infections in blood donors in Afyon region). Turk Bull Hygiene Exp Biol 2001, 58:61-66.

35. Sakarya S, Öncü S, Öztürk B, Öncü S: Effect of prevantive applications on prevalence of HBV and HCV infection in West Turkey. Saudi Med J 2004 25:1070-1072.

36. Heper Y, Yılmaz E, Akalın H, Töre O: Prevalences of transfusion transmissible markers in donors over a 6-year period. Vox Songuinis 2004, S3 100.

37. Koçak N, Sönmezoğlu M, Çetinkaya F: İstanbul'da farklı kan merkezlerinden alınan donör kanlarında üç yıllık HBV, HCV ve HIV seroprevalansının oranlarının karşılaştırılması (Comparison of seroprevalence rates of donors applied to several blood banks in İstanbul). J Klimik 2003, 16:366.

38. Küçükateş E, Bilgen H, Çavuşoğlu Ş, Öncül O: i.ü. Cerrahpaşa kan merkezi $\mathrm{HBsAg}$, anti-HCV, anti-HIV ve sifiliz taraması (HBsAg, anti-HCV, anti-HIV and syphilisis screening in Istanbul University Cerrahpasa Blood Bank). J Klimik 2005, 18(Suppl 1):319.

39. Biçer S, Ulucaklı Ö, Yüce O, Sezer S, Engerek N, Aldemir H: Kan merkezlerinde bakılan donör tarama testlerinin 4 yıllık değerlendirmesi (Evaluation of four years results of donor screenig tests from various blood banks). J Klimik 2005, 18(Suppl 1):323.

40. Yazan-Sertöz R, Pullukçu H, Altuğlu İ, Karadoğan A, Aydıncık Y: Sık kan bağışlayan kan vericilerinde infeksiyon göstergeleri (Infection markers of blood donors). Turk J Infect 2003, 17:77-79.

41. Kuzucu Ç, Yücel M, Karakoç E, Acar N: Ankara Eğitim ve Araştırma Hastanesine Kan Merkezine başvuran donörlerin HBV, HCV, HIV veVDRL (RPR) testlerinin 5 yıllık değerlendirilmesi (Evaluation of HBV, HCV, HIV and VDRL tests of donors applied to Ankara Training and Research Hospital within a 5 year period). J Turk Microbiol Soc 2001, 31:250-254.

42. Turunç $T$, Sezgin N, Uncu H, Demiroğlu Y, Arslan H: Kan donörlerinde HB veHC seroprevelansı (Seroprevalence of hepatitis B and $\mathrm{C}$ in blood donors). Viral Hepatitis J 2003, 9(8):171-173.

43. Karabay O, Şencan İ, Kayaş D, Şahin İ: Batı Karadeniz Bölgesi kan donörlerinde $\mathrm{HbsAg}$ ve anti-HCV prevalansı (Prevalence of HBsAg and anti-HCV in blood donors in western Black Sea region of Turkey). Viral Hepatitis J 2002, 8:502-504.

44. Uyar Y, Cağlar A, Balcı A: Samsun Doğum Ve Çocuk Bakımevi Kan İstasyonunda 2002 Yılında Başvuran Donörlerin Kan Grupları Ve Serolojik Sonuçlarının Değerlendirilmesi (Evaluation of blood types and serologic results of donors applied to Samsun Obstetrics and Perinatalogy Hospital Blood Bank). J Klimik 2003, 16:366.

45. Sümer Z, Sümer H, Bakıc M, Koç S: Cumhuriyet Üni Tıp Fakültesi Kan Merkezi Donör Kanlarının HBsAG, Anti-HCV, Anit-HIV ve sifiliz seropozitifliği yönünden değerlendirlimesi.(Evaluation of seropositivity of HBsAg, anti-HCV, anti-HIV and syphilis of donor blood samples applied to Cumhuriyet University Blood Bank). Viral Hepatitis J 2001, 7(2):330-332.

46. Ocak S, Duran N, Savas L, Onlen Y, Dibek M: Hatay bolgesindeki kan donerlerinde HBV, HCV, HIV ve VDRL seropozitifligi (HBV, HCV, HIV and VDRL seropositivity in blooddonors in Hatay province). Viral hepatit dergisi 2005, 10(1):49-53.

47. Kökoğlu Ö, Geyik M, Uçmak H, Aslan S, Ayaz C, Hoşoğlu S: Diyarbakır ilinde kan donörlerinde $\mathrm{HbsAg}$ ve anti-HCV prevalansı (Prevalence of $\mathrm{HBsAg}$ and Anti-HCV in blood donors in Diyarbakır). Viral Hepatitis J 2003, 9(8):56-59.

48. Erol S, Şahin Ü, Özkurt Z, Yer A, Bozhalil S: Erzurum yöresindeki kan donörlerinde $\mathrm{HbsAg}$, anti-HCV, anti-HIV ve VDRL(RPR) seroprevalansı (Seroprevalence of HBsAg, anti-HCV, anti-HIV and VDRL(RPR) $n$ blood donors in Erzurum region). J Turk Microbiol Soc 2001, 31:243-249.

49. Arabacı F, Sahin H, Sahin I, Kartal S: Kan donörlerinde HBV, HCV, HIV ve VDRL seropozitifliği (HBV, HCV, HIV and VDRL seropositivity in blood donors). J Klimik 2003, 16:18-20.

50. Apaz T, Yırdırım R, Yıldız A, Begon B: Kırıkkale ilinin devlet hastanesi ve Kırıkkale Üniversitesi Tıp Fakültesine Başvuran Hastalarda hepatit B 
seroprevalansı (Hepatitis B seroprevalence in Kırıkklae Government Hospital and Kırıkkale University Hospital). Viral Hepatitis J 2002, 8:509-513.

51. Kaçmaz B: Ankara llinde HBV ve HCV seroprevalansı (HBV and HCV seroprevalence in Ankara). Viral Hepatitis J 2003, 9(8):97-101.

52. Delialioğlu N, Öztürk C, Aslan G: Mersin ilinde HBsAg, Anti-HBs, anti-HCV ve anti-HDV seroprevalansı (Seroprevalence of HBsAg, anti-HBs, anti-HCV and anti-HDV in Mersin). Viral Hepatitis J 2001, 7(3):416-418.

53. Özden M, Demirdağ K, Kalkan A: Hastanemizde üç yıllık HBV ve HCV markerlarının değerlendirilmesi (Evaluation of HBV and HCV markers of a three years period in our hospital). Viral Hepatitis J 2003, 9(8):116-118.

54. Aslan G, Ulukanlıgil M, Seyrek A: Şanlıurfa ilinde HBsAg, Anti-HBs, anti-HCV seroprevalansı (HBsAg, anti-HCV seroprevalence in Şanlıurfa). Viral Hepatitis J 2001, 7(3):408-410.

55. Börekçi G, Otağ F: Sağlıklı gebelerde HBV, HCV ve HIV seroprevalansı ve risk faktörlerinin belirlenmesi (Prevelance of HBV, HCV and HIV and releted risk factors in pregant women). Turk J Infect 2004, 18:219-223.

56. Uyar $Y$, Cabar $C$, Balci A: Seroprevalence of hepatitis B virus among pregnant women in northern Turkey. Hepatitis Monthly 2009, 9(2):146-149.

57. Nas T, Taner MZ, Yildiz A: Seroprevalence of syphilis, human immunodeficiency virus type-1, and hepatitis B virus infections among pregnant women in Turkey. Int I Gynaecol Obstet: Official Organ Int Fed Gynaecol Obstet 1999, 66(2):171-172.

58. Erdem H, Oncu S, Pahsa A: Prevalence of hepatitis B virus infection in young Turkish men. Trop Doct 2005, 35(3):192.

59. Altindis M, Yilmaz S, Dikengil T, Acemoglu H, Hosoglu S: Seroprevalence and genotyping of hepatitis $B$, hepatitis C and HIV among healthy population and Turkish soldiers in Northern Cyprus. World J Gastroenterol 2006, 12(42):6792-6796.

60. Emiroglu H, Altinay H, Oguz S: Prevalence of Hepatitis B Virus Carrieres among soldiers and civilians in Turkey. J Clin Gastroenterol 2004 38(7):614-615.

61. Kaygusuz S, Cuhadir F: Askerkerde HBsAg arastirmasi (HBsAg screening in military recruits). Viral Hepatit Dergisi 2001, 7(1):260-262.

62. Tumer C, Tasar F, Bayik S: Turk dis hekimlerinde hepatit B gorulme sikligi (Hepatitis B prevalence among Turkish dentists). Ankem Derg 1992, 6:237-238

63. Goz M, Misirligil A, Cengiz A, Kiyan M, Gerceker D: Tip ve Dis hekimligi fakultesinin hekim, memur, ve hastane personelinden olusan bir grup calisanlarinda HbsAg'nin ELISA ile arastirilmasi (Measuring HBsAg prevalence in a medical faculty among Medical personnel dentists, and hospital personel using ELISA method). Enfeksiyon Derg 1993, 7:259-263.

64. Saritas U, Kantaroglu A, Yildirim B, Saydam G, Yilmaz U: Turkiye yuksek intisas hastanesi saglik personelinde HBV prevalansi (HBV prevalence among Turkiye Yuksek Ihtisas hospital medical personnel). Gastroenteroloii 1994, 5:147-148

65. Tunabilek S, Dokuzoguz S, Ozturk S: Acil servis personeli ve HBV enfeksiyonu (HBV infection and emergency department personel). Viral Hepatit Dergisi 1995, 1(1):25-28.

66. Kurt H, Turcapar N, Balik I, Tekeli M, Meco O: Yuksek risk grubunda olan saglik calisanlarinda viral hepatit enfeksiyon sikligi (Viral hepatitis infection in the high risk population medical personnel). Viral hepatit derg 1997, 11:56-59.

67. Baykam N, Dokuzoguz B, Bodur H, Ariturk N, Alpagut S: Saglik personelinde hepatit $B$ ve $C$ seroprevalansi (Hepatitis B and C prevalence among medical personnel). Viral hepatit Derg 1997, 3(1):66-69.

68. Hizel K, Sengul A, Emekdas G, Senol E, Inal A: Hastane personelinde hepatit $B$ seroprevaleansi ve rekombinant hepatit B asisina imun cevap (Hepatitis B prevalence among hospital personnel and the immuun response to the recombinant hepatitis B vaccination). Viral Hepatit Derg 1998, 4(1):25-27.

69. Otkun M, Akata F, Uzun C, Sagdic A, Karabay O, Karakurt S, Tugrul M: Trakya universitesi egitim uygulama ve arastirma hastanesi calisanlarda hepatit B virus enfeksiyonu (Hepatitis B infection among medical personnel in Trakya university hospital). Klinik Derg 1999, 7:79-81.

70. Bahar I, Hashempoor R, Yucesoy M, Yulug N, Bozkaya A, Akcay H, Kocaman G: Bir meslek hastaligi olarak iki ayri hastanede hepatit B taramasi (Hepatitis B screening in two different hospital settings among medical personnel). Infeksiyon Derg 1993, 7:265-267.

71. Mandiracioglu A, Ozacar T, Sacaklioglu F, Bilgic A, Yildiz I: Bornova egitim ve arastirma bolgesi saglik ocaklarinda calisan saglik personelinin hepatit $B$ ve $C$ karsilasma yonunden arastirilmasi (Hepatitis B and C scereening among medical personnel in Bornova research center). Infeksiyon Derg 1994, 8:7-9.

72. Leblebicioglu H, Gunaydin M, Durupinar B: Hastane personelinde hepatit B seroprevalansi (Hepatitis B seroprevalence among medical personnel). Mikrobiyol Bult 1993, 27:113-118.

73. Cetinkaya F, Gurses N, Aydin M, Albayrak D: Cocuk hastanesi personeli hepatit B seroprevalansi (Hepatitis B prevalence among medical personnel in a childrens hospital). Mikrobiyol Bult 1994, 28:246-249.

74. Berktas M, Dalkilic AE, Yavuz ME: Yuzuncu yil U. Tip fakultesi arastirma hastanesi personelinde hepatit B seroprevalansi (Hepatitis B seroprevalence among medical personnel in Yuzuncu yil university medical center). Viral Hepatit Derg 1995, 2:87-89.

75. Kosgeroglu N, Ayranci U, Vardareli E, Dincer S: Occupational exposure to hepatitis infection among Turkish nurses: frequency of needle exposure, sharps injuries and vaccination. Epidemiol Infect 2004, 132(1):27-33.

76. Ozsoy M, Emekdas G, Pahsa A: Saglik calisanlarinda HB ve HC seroprevalansi (HBV and HCV prevalence among healthcare workers). Viral hepatit Derg 2000, 2:71-74.

77. Ergonul O, Isik H, Baykam N, Erbay A: Ankara numune egitimi ve arastirma hastanesinde saglik calisanlarinda HBV enfeksiyonu (HBV infection among healtcare workers in Ankara numune research hospital). Viral hepatit Derg 2001, 2:327-329.

78. Ozbolubasi FF, Yildi Seyrek F, Bolukbasi C: Hasta bakim ve hastane hijyeniniden sorumlu saglik personelinde HBV, HCV ve HIV sikligi (HBV, $\mathrm{HCV}$ and HIV prevalence among personel responsible for patient care and hygiene). Viral hepatit Derg 2003, 9:89-92.

79. Iris NE, Dinc E, Onlem Y, Savas L, Ozqunes N: Saglik personelinin HBV ile karsilasma orani (The chances of medical personal coming in contact with HBV). Viral hapatit derg 2002, 8:540-541.

80. Sencan I, Sahin I, Kaya D, Bahtiyar Z: Yeni kurulan bir Tip fakultesi hastanesinde saglik calisanlarinin hepatit $B$ ve $C$ seroprevalansi (Hepatitis B and C seroprevance among healthcare workers in a new builth university hospital). Viral hepatit Derg 2003, 8:47-50

81. Ayyildiz A, Aktas A, Yigit N, Uslu H: Ataturk U. Dis hekimlige calisanlarinin hepatit $B$ ve $C$ yonunden incelenmesi (Hepatitis B and C screening among dentists in Ataturk university). Viral hepatit derg 2000, 2:113-115.

82. Kose S, Sanca A, Caglan-Cevik F, Cuce M: Saglik calisanlarinda viral hepatit $A, B$ ve $C$ seroprevalansi (Viral hepatitis A, B and C seroprevalence among medical personnel). 2003, 8:152-154.

83. Uyar Y, Cabar C, Acunur İç, Cabaz S: Hastane sağlık çalışanlarında HBV ve HCV serolojik belirteçlerinin prospektif taranması ve proflaktik aşı uygulanması (Prospective screening of HBV and HCV serologic markers and vaccination of healthcare workers in hospital). J Klimik 2005, 18:321.

84. Kulekci G, Balkanli O, Inanc D, Guvener Z: Dis hekimliginde hepatit B prevalansi (Hepatitis B prevalence in dentistry). Turk Mikrobioyol Cem Derg 1991, 21:109-117.

85. Kosar A, Sunbul M, Sanic A, Alici S: Tip ogrencileri ve saglik personelinde $\mathrm{HbsAg}$ ve anti-HBs pozitifligi ( $\mathrm{HBsAg}$ and anti-HBs positivity among medical students and personnel). Mikrobiyol But 1995, 29:52-57.

86. Goz M, Misirligil A, Cengiz A, Kiyan M: Tip ve dis hekimligi ogrencilerinde $\mathrm{HbsAg}$ arastirmasi (HBsAg screening among medical and dentistry students). Infeksiyon Derg 1992, 6:253-256.

87. Oncu S, Oncu S, Sakarya S: Hepatitis A and B seropositivity among medical students. Health Policy 2005, 74:39-45.

88. Candan F, Alagozlu H, Poyraz O, Sumer H: Prevalence of hepatitis B and C virus infection in barbers in the Sivas region of Turkey. Occup Med (Oxford, England) 2002, 52(1):31-34.

89. Olut A, Özürlü H, Karacan S, Özsakarya F: İzmir'deki çöp işçilerinde hepatit $B, C$ ve $E$ virusu seroprevalansı (Hepatitis $B, C$ and $E$ seroprevalence in garbagemen in İzmir). Flora 2004, 9:271-273.

90. Ceylan A: Diyarbakir'da genel kadin, pavyonda calisan kadin ve dusuk sosyoekenomik duzeyindeki kadinlarda $\mathrm{HbsAg}$, anti-HBs, anti-HCV prevalenasi ( $\mathrm{HBsAg}$, anti-HBs and anti-HCV prevalence among female sex workers and women in low socioeconomical status). Viral hepatiti dergisi 2001, 7(2):987-101.

91. Vandenbroucke JP, von Elm E, Altman DG, Gotzsche PC, Mulrow CD, Pocock SJ, Poole C, Schlesselman JJ, Egger M: Strengthening the Reporting of Observational Studies in Epidemiology (STROBE): explanation and elaboration. PLoS Med 2007, 4(10):e297.

92. Kanra G, Tezcan S, Badur S, Team TNS: Hepatitis B and measles seroprevalence among Turkish children. Turk J Pediatr 2005, 47(2):105-110. 
93. Mahoney FJ, Stewart K, Hu H, Coleman P, Alter MJ: Progress toward the elimination of hepatitis B virus transmission among health care workers in the United States. Archives Internal Med 1997, 157(22):2601-2605.

94. Toy M, Veldhuijzen IK, de Man RA, Richardus JH, Schalm SW: Potential impact of long-term nucleoside therapy on the mortality and morbidity of active chronic hepatitis B. Hepatology 2009, 50(3):743-751.

95. Toy M, Önder FO, Richardus JH, Kuloglu Z, Kansu A, Kabacam G, Bozkaya H, Idilman R, Schalm SW, Yurdaydin C: The Burden of chronic hepatitis B in a median endemic country; a mathematical approach. AASLD Liver meeting Boston 2009 2009, Abstract number: 404.

96. Veldhuijzen $\mathbb{I K}$, Smits $\sqcup$, van de Laar MJ: The importance of imported infections in maintaining hepatitis B in The Netherlands. Epidemiol Infect 2005, 133(1):113-119.

97. Jaroszewicz J, Calle Serrano B, Wursthorn K, Deterding K, Schlue J,

Raupach R, Flisiak R, Bock CT, Manns MP, Wedemeyer H, et al: Hepatitis B surface antigen ( $\mathrm{HBsAg}$ ) levels in the natural history of hepatitis $B$ virus (HBV)-infection: a European perspective. J Hepatol 2010, 52(4):514-522.

\section{Pre-publication history}

The pre-publication history for this paper can be accessed here:

http://www.biomedcentral.com/1471-2334/11/337/prepub

\section{doi:10.1186/1471-2334-11-337}

Cite this article as: Toy et al:: Age- and region-specific hepatitis B prevalence in Turkey estimated using generalized linear mixed models: a systematic review. BMC Infectious Diseases 2011 11:337.

\section{Submit your next manuscript to BioMed Central and take full advantage of:}

- Convenient online submission

- Thorough peer review

- No space constraints or color figure charges

- Immediate publication on acceptance

- Inclusion in PubMed, CAS, Scopus and Google Scholar

- Research which is freely available for redistribution

Submit your manuscript at www.biomedcentral.com/submit 